\title{
LEARNING STRATEGIES AND TECHNOLOGIES: CHALLENGES FOR ONLINE ENVIRONMENTS.
}

Mateus Cardoso Coutoa; Diego Henrique de Andrade Santos Siqueria; Pedro Donner Carvalho ${ }^{\text {; }}$ Herman Augusto Lepiksona

aSENAI CIMATEC; Salvador/Bahia

\begin{abstract}
The virtualization process was accelerated by the impact of COVID-19. Thus, it is necessary that institutions, on an emergency basis, adopt the use of new technologies and strategies, including the opportunity to improve the art of teaching in a virtualized way. This article aims to present evolving solutions in the educational sector, taking in account to the impacts generated by the pandemic. It is presented virtual learning environments and educational methods for online, collaborative teaching platforms. Management tools for student autonomy and teacher empathy are introduced as well.
\end{abstract}

Keywords: Active Methodologies; Virtual Learning Environments; Educational Methods; Learner Autonomy; E-Learning.

Resumo: O processo de virtualização foi acelerado pelo impacto do COVID-19. Desta forma, é necessário que as instituições, em caráter emergencial, adotem o uso de novas tecnologias e estratégias, incluindo a oportunidade de aprimorar a arte de ensinar de forma virtualizada. Este artigo tem como objetivo apresentar soluções em evolução no setor educacional, levando em consideração os impactos gerados pela pandemia. São apresentados ambientes virtuais de aprendizagem e métodos educacionais para plataformas de ensino on-line colaborativas. Também são introduzidas ferramentas de gerenciamento para autonomia dos alunos e empatia dos professores.

Palavras-chave: Metodologias Ativas; Ambientes Virtuais de Aprendizagem; Métodos educacionais; Autonomia discente; E-Learning. 


\section{INTRODUCTION}

Approximately $95 \%$ of the child audience in Latin America and the Caribbean is currently outside the classroom educational environment [7]. Increasing to a global perspective, more than $90 \%$ of students (1.58 billion people) were affected by measures to prevent the contagion of COVID-19 [6]. As shown in Figure 1, almost all countries (194 in April) have adopted control measures in the educational field.

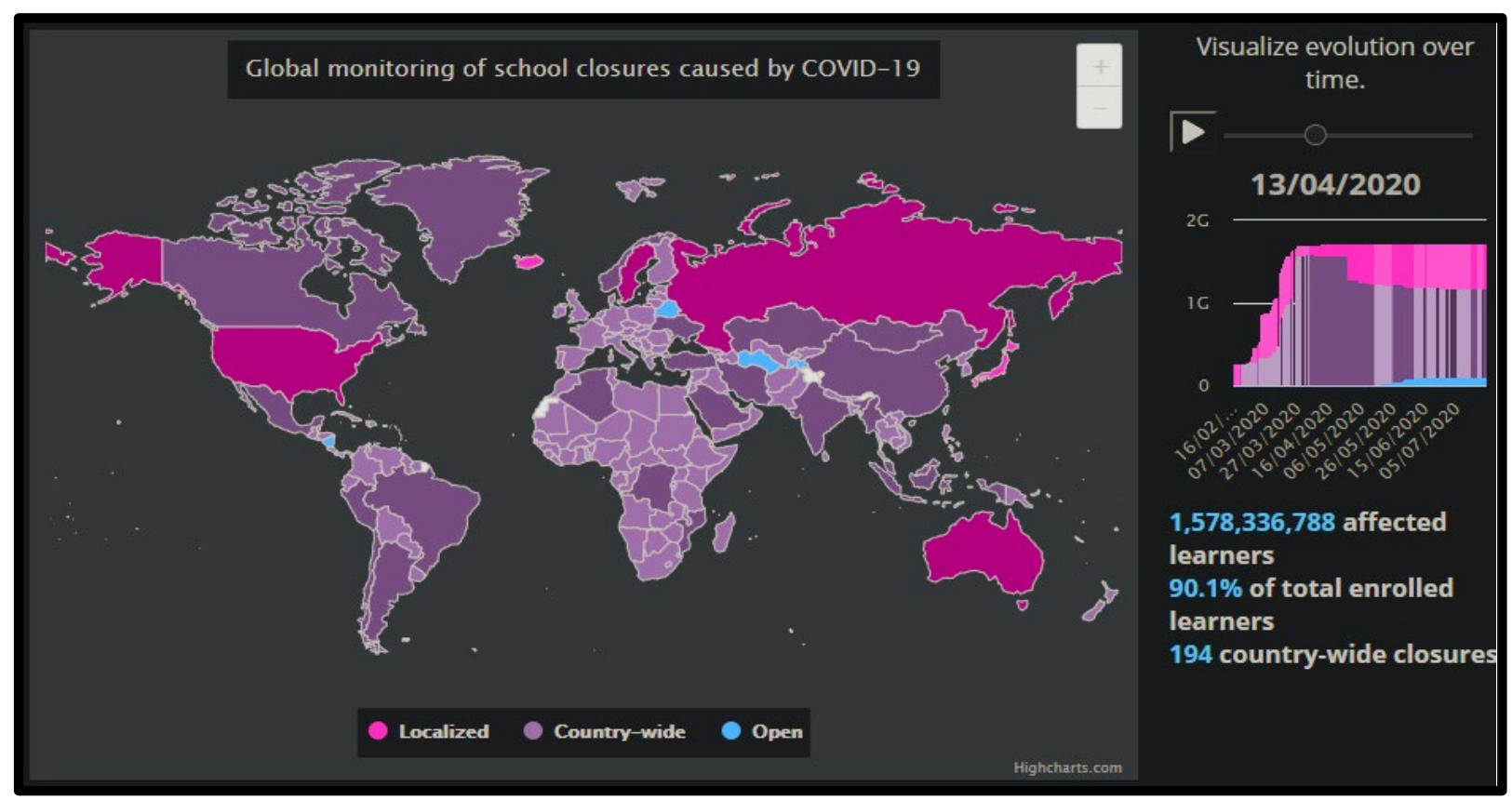

Figure 1: Impacts on education centers caused by COVID-19. [6]

Education centers across the globe have adopted and/or reinforced their online teaching strategies. Digital learning environments, tools, virtualization actions and empowering training are often found in institutions. However, even with all this effort, the big question still asked around the world is: what are the necessary premises for the virtualization of learning to become effective? The present work presents the educational tools and methods in remote environments available for use in online classes, discursive and/or practical, showing how the teaching-learning process can be stimulated.

\section{VIRTUAL LEARNING ENVIRONMENTS}

There are two broad categories of learning in digital environments: distance learning and online teaching (e-learning). The distance learning is a set of materials, recordings and resources that the student only listens to and reads. E-learning, on the other hand, works with teachers in real time in the educational process of the participants, in a custom and constructive way.

The interaction of the virtualized classroom can occur both by computers and laptops (phones and tablets), in the most varied ways. Digital environments such as Google Classroom, Moodle, Discord, Microsoft Teams, Webex, Google Meet or even 
programmed environments, by the institution itself, can be used for meetings and foruns between teachers and students who are in remote environments. Social networks and content providers have also intensified, in educational use, as they facilitate communication methods where greater agility is needed [2].

These environments consist of interactive virtual spaces where members can chat by video calls, access materials, open a discussion foruns, share their screens, watch media together and even review activities. Virtualization is also present in practical classes in laboratories or for the preparation of a project. For example, Autodesk (2020), responsible for the Revit, Autocad, Inventor, Fusion, and Tinkercad programs (Figure 2), provides cloud platforms so that teachers and students can work collaboratively and applied theoretical and practical knowledges. As well as these platforms, there are others with cloud access and collaboration that have licenses for students and teaching centers.

Figure 2: Tinkercad, a program that offers resources for classes in electronics, programming logic, robotics and 3D printing. The authors.

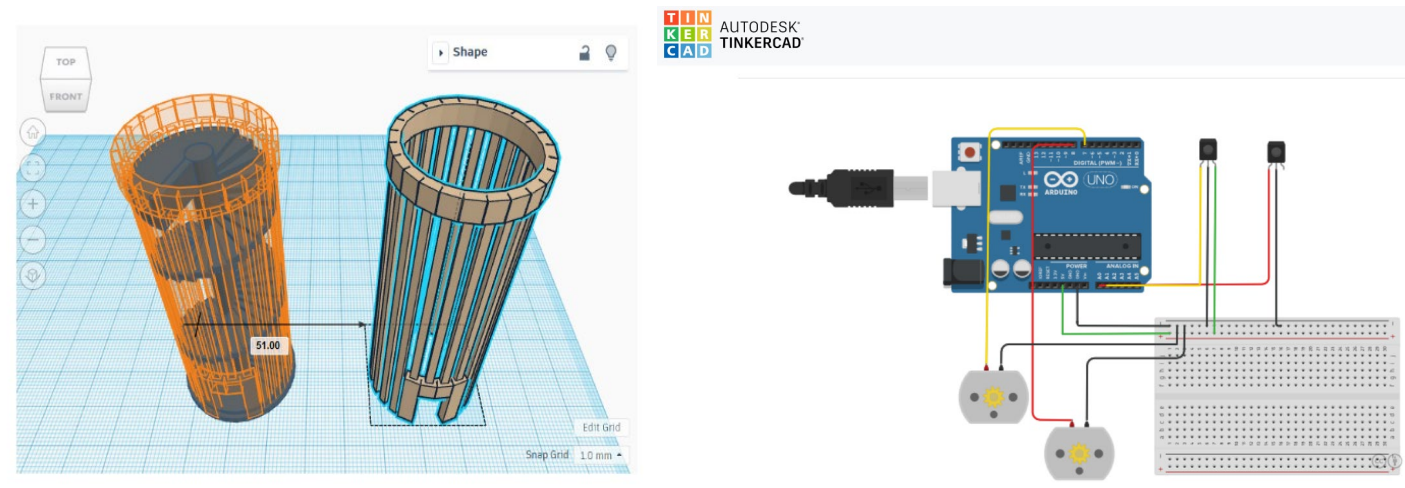

\section{EDUCATIONAL METHODS FOR VIRTUAL ENVIRONMENTS}

It is suggested to use active methodologies within virtual environments so that a greater level of interactivity between students occurs. In this way, the frequency of the use of digital resources is amplified to increase the level of discussions and solutions.

In the same way that face-to-face education is conducted, online teaching has some premises that must be considered as elements of success for a good learning management. During the selection of the virtual environment, the teacher and/or responsible institution should consider the following guiding questions for online learning:

i. Which of the virtual environments has the best synergy to the profile of the institution and the requested teacher?

ii. What are the main characteristics that the selected component addresses?

iii. Which student profile will attend the specific component?

iv. What are the educational methodologies that best match the teaching profile and virtual environment used for online teaching?

After reflecting on these questions, it is essential to instruct that the new role of the teacher is to be a content manager in the environment he acts, receiving and 
distributing information with active curation and backward design. The availability of communication materials and strategies must be described and passed in a explicitly way to the members. Starting from the requirement that the virtualized space allows the active dialogue of its constituents thanks to online learning.

It is important to highlight that there is no single virtual environment, methodology with higher performance, miraculous support tools or means of communication for maximum effectiveness. Depending on the context where the metrics and strategies are applied, the results may vary, education occurs in a fluid and random way due to the diversity of its participants.

Figure 3: Quality of Online Education (QOE) framework. [5].

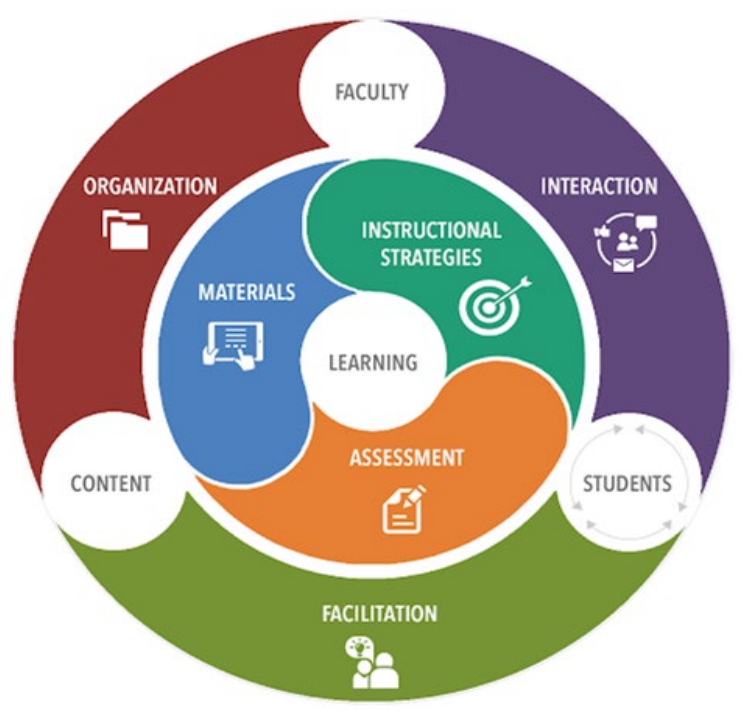

The American university TTU (Texas Tech University) created a strategy to guide its members through the Quality of Online Education framework (QOE, Figure 3 ). This resource divides three focal points (content, students and faculty) and six actions (organization, interactions, facilitation, materials, assessment and instructional strategies) to result in learning [5]. Each of the actions has the following objectives:

- Organization of structuring metrics an online course for an effective communication of expectations, contents and learning processes;

- Interaction can be achieved by building a community for students to share perspectives, interests and collaborate on tasks;

- Facilitation concerns on the implementation and ongoing monitoring in the pursuit of educational improvement of students;

- Materials consists of the creation and presentation of accurate, current and relevant content by teachers to increase students' interest in learning new knowledge;

- Assessment explains the design of the faculty and the use of various assessment methods to ensure the achievement of students' learning objectives;

- Instructional strategies describe faculty approaches and ways to engage students in deeper learning.

Based on these projected premises, the university models its virtual environments and its learning techniques, thus improving the quality of online teaching and the interaction of the respective members. 


\section{AUTONOMY AND EMPATHY AS SUCCESS FACTOR}

It is critical that the loads and complexities of activities are reassessed, so that, extra-class routines, such as domestic ones, do not negatively impact students' tasks and assessments, resulting in massive stress.

To reach a satisfactory level of academic activity, empathy is necessary in the teacher's conduct. The empathic projection must be measured in order to be not low enough to ignore the conditions of the members of the class, or very high to impair the quality of teaching [8].

For achieving critical and systemic thinking, demands that are part of modern educational needs, it is necessary for teachers to guide their strategies based mainly on student autonomy [4]. Thus, and there are several strategies to foster learning autonomously. One of the simplest is the model generated by the University of Cambridge, presented by [3], which defines three points to achieve student autonomy (Figure 4): Learning to learn, critical thinking and collaboration.

Figure 4: Elements for encouraging learner autonomy. Adapted [3].

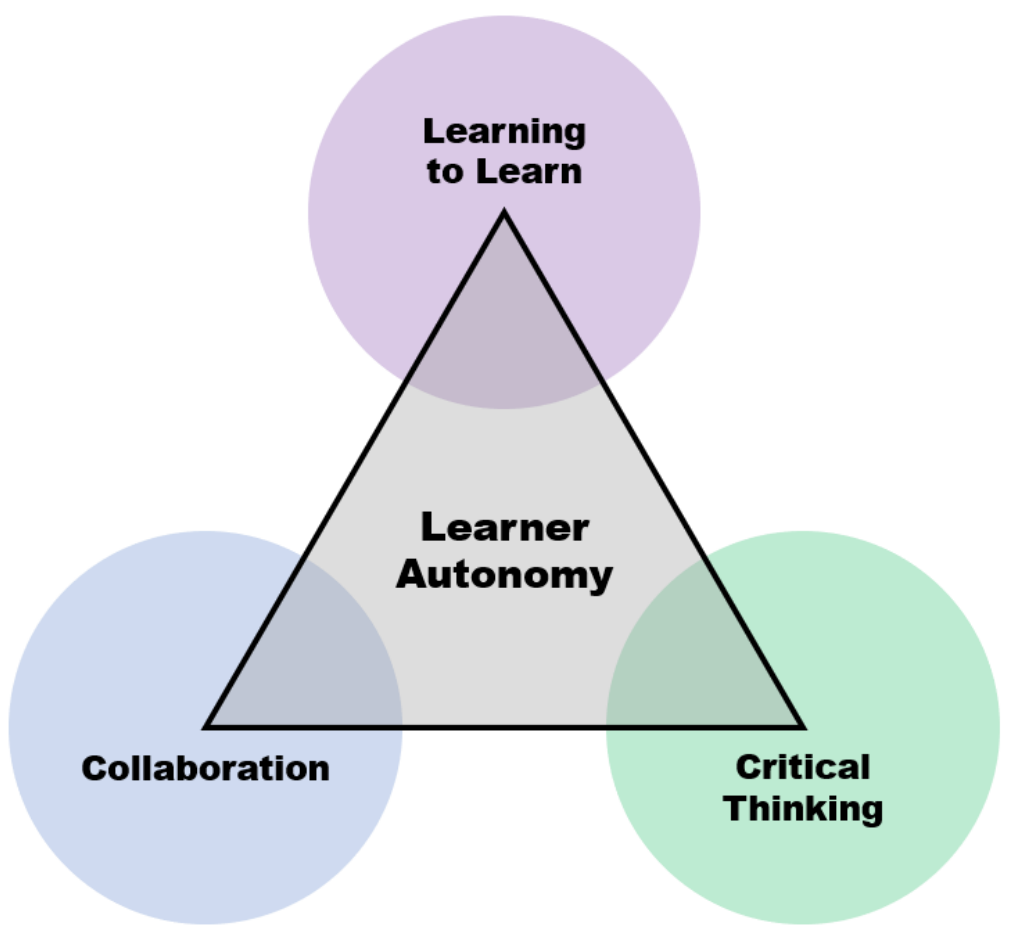

Each of these points can be better exemplified and understood by the flowchart described in Figure 5: 
Figure 5: Competencies Description. Source. Adapted [3].

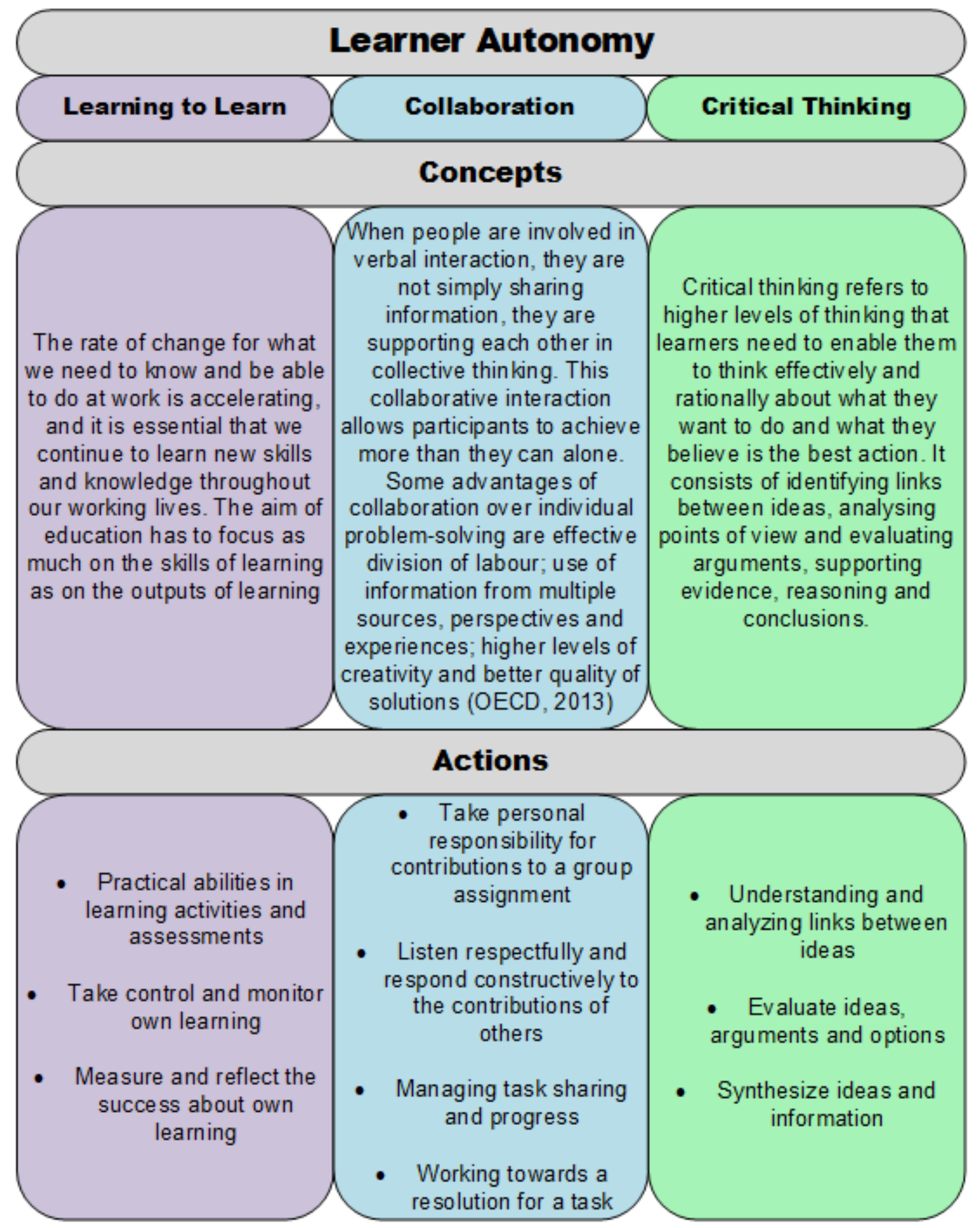

\section{CONCLUSION}

The global impact of COVID-19 accelerated the inevitability of the domain on digital management. Institutions must adapt to ensure effectiveness in the learning process of students in remote environments. 
However, only technical knowledge in the operation of technological resources and virtual environments is not sufficient to ensure success in acquiring students' knowledge and skills. To this end, it is necessary that in addition to having a technology, information and communication structure, the institution understands the context to which it is inserted. In other words, it is a duty to create and execute new teaching strategies with training on digital teaching, mainly focused on the autonomy and empathy of its members.

There are several educational models and strategic examples from different institutions that can assist in the process of the new conduct of online education. For there to be a greater possibility in obtaining success, the educational system can work with critical thinking, autonomous and collaborative learning integrated in the planning and execution of activities.

\section{REFERENCES}

[1] AUTODESK. Cloud services. Available at: https://www.autodesk.com/360-cloud. Accessed on: 11 jul. 2020.

[2] DA SILVA MONTEIRO, Sandrelena. INVENTAR EDUCAÇÃO ESCOLAR NO BRASIL EM TEMPOS DA COVID-19. Revista Augustus, v. 25, n. 51, p. 237-254, 2020.

[3] LEWIS, Samantha. Encouraging learner autonomy. 2019. Available at: https://www.cambridge.org/elt/blog/2019/09/19/encouraging-learner-autonomy/. Accessed on: 11 jul. 2020.

[4] SPENCER, John; JULIANI, A. J. Empower: What happens when students own their learning. Impress, LP, 2017.

[5] TTU. Quality of Online Education (QOE) framework. 2018. Available at: http://edit.educ.ttu.edu/qoeweb/index.html. Accessed on: 09 jul. 2020.

[6] UNESCO. Education: From disruption to recovery. 2020. Available at: https://en.unesco.org/covid19/educationresponse. Accessed on: 16 jul. 2020.

[7] UNICEF. Covid-19: Mais de 95\% das crianças estão fora da escola na América Latina e no Caribe. 2020. Available at: https://www.unicef.org/brazil/comunicados-deimprensa/covid-19-mais-de-95-por-cento-das-criancas-fora-da-escola-na-america-latina-ecaribe. Accessed on: 16 jul. 2020.

[8] WAYTZ, Adam. The limits of empathy. Harvard Business Review, v. 94, n. 1, p. 68-73, 2016. 